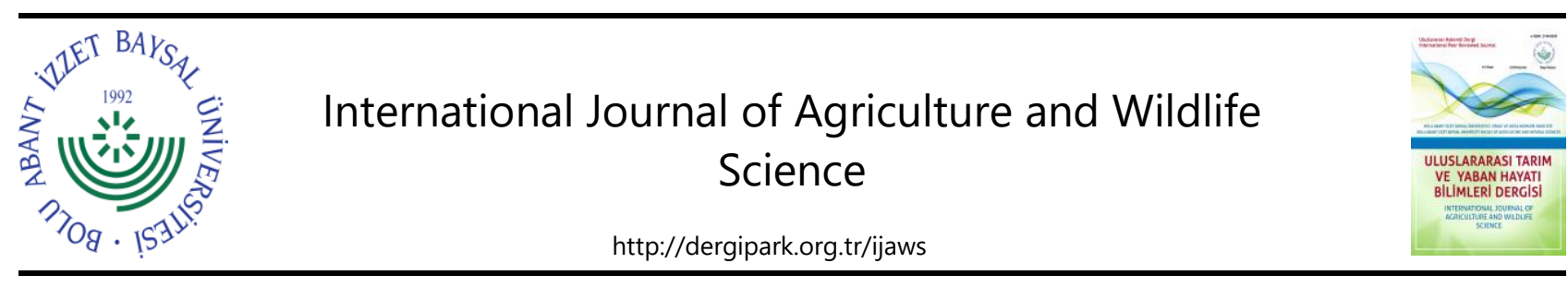

Research Article

\title{
Effect of Different Organic Manures Application on the Bioactive Compound and Yield of Taşköprü Garlic (Allium sativum L.) under 50\% Drought
}

\author{
Nezahat Turfan \\ Biology, Science and Art Faculty, Kastamonu University, Kastamonu, Turkey
}

Received: 01.02.2021 Accepted: 19.04.2021

\begin{abstract}
Keywords:
Chemical, drought, garlic, manure, taşköprü

*Corresponding author

nturfan@kastamonu.edu.tr

Abstract. This study was carried out to assess the contribution of different organic fertilizer mixtures [(CONTROL (open field), CATTLE, CHICKEN, GOAT, IMPORTED PEAT (IPT), NATIVE PEAT (NPT), FIELD SOIL (FS: in greenhouse)] to drought tolerance of Taşköprü garlic, which was exposed to $50 \%$ water deficiency under greenhouse conditions. For this purpose, the measurement of yield was performed with bulbs, but the amount of some bioactive chemicals as chlorophyll, carotenoid, flavonoid, phenolic, proline, protein, free amino acid, sugars, pyruvic acid, malondialdehyde (MDA), hydrogen peroxide $\left(\mathrm{H}_{2} \mathrm{O}_{2}\right)$, ascorbate peroxidase (APX) and superoxide dismutase (SOD) activities obtained from the fresh leaf and cloves grown in the different soil mix. According to the result, while the amount of pigment was found to be higher in the leaf of FS and FS-IPT, the flavonoid in FS-CHICKEN and total phenolic in FS-CATTLEGOAT samples, nitrogenous compounds, and sugars (glucose, sucrose) were found to be rich in the control group (open field). The measurement of bulb weight, length, diameter, and the amount of lycopene, flavonoid, total phenolic, and free amino acid of garlic cloves obtained from FS-CHICKEN-IPT, FS-CATTLE-GOAT, FS-CHICKEN-GOAT, and FS-GOAT-NPT was higher when compared to the control. Furthermore, APX and SOD increased, whereas malondialdehyde lowered in these samples. As a result, the amounts of bulb yield, enzymatic and non-enzymatic compound, and sugars estimated using organic fertilizer were higher than the control, which was grown with inorganic fertilizer in an open field. In addition, the most drought-susceptible examples are the samples of FS, FS-ITP, FS-NTP, and FSCATTLE soils considering all data.
\end{abstract}

\section{Farklı Organik Gübre Uygulamalarının \%50 Kurak Stresi Altındaki Taşköprü Sarımsağının (Allium sativum) Biyoaktif bileşenleri ve Verim Üzerine Etkileri}

\section{Anahtar kelimeler:}

Kimyasal, kurak, gübre, sarımsak, taşköprü
Özet. Bu çalışma, farklı organik gübre karışımlarının [(kontrol (tarla), sığır, tavuk, keçi, ithal torf (PT), yerli torf (NPT), tarla toprağı (FS: serada tarla toprağı)] sera koşulları altında \%50 su eksikliğine maruz bırakılan Taşköprü sarımsağında kuraklığa dayanımdaki etkilerini ölçmek için gerçekleştirilmiştir. Bu amaçla sarımsak başlarında verim ölçümleri yapılırken yaprak ve dişlerde pigment, flavonoit, fenolik bileşik, prolin, protein, serbest amino asit, şekerler (glikoz, sukroz), pürivik asit, malondialdehit (MDA), hidrojen peroksit $\left(\mathrm{H}_{2} \mathrm{O}_{2}\right.$ ), askorbat peroksidaz (APX) ve süperoksit dismutaz (SOD) gibi bazı biyoaktif bileşiklerin miktar tayinleri ölçülmüştür. Sonuçlara göre fotosentetik pigment içeriği FS ve FS-IPT yapraklarında yüksek bulunurken flavonoit miktarı FS-CHICKEN, toplam fenolik FS-CATTLE örneklerinde, azotlu bileşikler ve şeker miktarı ise kontrol grubu (açık alan) bitkilerde yüksek bulunmuştur. Baş ağırlığı, uzunluk, çap ölçümleri ve ayrıca likopen, flavonoit, toplam fenolik ve serbest amino asit miktarı FSCHICKEN-IPT, FS-CATTLE-GOAT, FS-CHICKEN-GOAT ve FS-GOAT-NPT örneklerinde daha yüksek belirlenmiştir. Hatta bu örneklerde askorbat peroksidaz ve süperoksit dismutaz aktivitesi artış göstermiş ancak MDA azalmıştır. Sonuç olarak, baş verimi, şeker içerikleri, enzimatik ve enzimatik olmayan biyoaktif bileşenler organik gübre ile yetiştirilen bitkilerde açık alanda inorganik gübre ile yetiştirilen örneklerden daha yüksek bulunmuştur. Ayrıca tüm veriler göz nünde bulundurulduğunda kuraklığa en duyarlı örnekler FS, FS-ITP, FS-NTP ve FS-CATTLE olmuştur. 


\section{INTRODUCTION}

Garlic is a widely cultivated spice crop that is used for food and medicinal purposes. The green parts of this crop are freshly consumed or cooked, especially in tropical areas and the raw use of immature bulbs in the salad is also popular (Adewale et al., 2011). The economic importance of the garlic crop has greatly increased in the entire world in recent years. Despite its importance, several problems, such as drought, organic matter and mineral deficiency/toxicity, salinity, or some diseases, are encountered during the growth period (Shafeek et al., 2015). In Kastamonu, the selenium level identified with garlic is sufficient in the soils of the garlic cultivation areas; however, the organic matter and some trace elements are insufficient (Kaçar et al., 1998; Akça et al., 2017). Taban et al. (2004) reported that $67.5 \%$ of the soil is insufficient for $\mathrm{N}(40 \%), \mathrm{P}(85.5 \%), \mathrm{K}(95 \%), \mathrm{Zn}$ and $\mathrm{Mn}(7.5 \%)$, and Fe and $B(67.5 \%)$. In addition, the use of natural manures (sheep/goat, chicken, and cattle) and peat, enrich the organic status of the soil. Studies have shown that the use of manure (cattle, chicken, goat, or sheep), herbal and urban wastes (Can et al., 2019; Doğan et al. 2020), and composts in the cultivation of many crops, increases the tolerance of plants to drought by improving soil properties and water-holding capacity, which results in the availability of the nutrients available to plants by root cells, thus increasing the yield and quality per unit area (Mahmoody et al., 2014; Zhang et al., 2016). Garlic can only be planted in areas where its root can uptake maximum water and mineral, with the soil moisture level close to the field capacity $(60 \mathrm{~cm}$ from the soil surface), since garlic has a shallow root structure (Taban et al., 2004; Acharya and Kumar, 2018). In addition, the stage at which garlic mostly requires water is during bulb formation and water deficiency, since this stage can result in reduced bulb quality, yield, and storage time (Rekowska et al., 2008; Abou El-Magd et al., 2012). Drought stress is among the most important suppressing factors that adversely affect growth and development, which results in reduced yield, quality and storage time of some fruits, bulbous species, roots, and stems that store nutrients. It is reported that the severity of the damage caused by drought on plants is closely related to the phases of the life cycle of the species. For instance, the drought that occurs at the initial growth phases (where energy consumption at the highest level can be lethal for the plant (Yazgan et al., 2008; Hussein et al., 2018). A most common effect of water deficiency on crops is a reduction in fresh weight which results in declination of both elongation and expansion of leaf (Farooq et al., 2009; Temesgen et al., 2018; Kurt et al., 2020). Producers during the drought periods may reduce the number of hectares cultivated, thereby cultivating only drought-resistant cultivars. However, the use of organic fertilizers and the selection of resistant genotypes is now a common practice it effectively increases the yield and quality of agricultural products by stimulating drought tolerance (Shafeek et al., 2013; Rahman et al., 2018). There are studies investigating the factors that affect the growth, development, bulb yield, and quality of garlic; however, there are limited studies on the effects of organic manure application on drought-resistant Taşköprü garlic. The main purpose of this study was to investigate the effects of natural organic manures (cattle, chicken, and goat) and peat on drought stress tolerance level of Taşköprü garlic grown in an open field and greenhouse conditions under the drought. In this context, the most important quality criteria for garlic were examined and they include: the amount of bioactive compounds in the leaves and cloves; bulb weight, length, and diameter measurement, and cloves number. This investigating is the first study conducted to determine the effects of organic fertilizers on the drought-stress resistance of Taşköprü garlic in Kastamonu.

\section{MATERIAL AND METHOD}

\section{Cultivation Experiment}

This study was performed in an open field and under greenhouse conditions, in Kastamonu for approximately 5 months (24 February-13 July 2016). The field experiment was performed in the Taşköprü district, while the greenhouse experiment was set up in the Kastamonu University plastic greenhouse. For the open field experiment, big sized cloves were cultivated with a spacing of $10 \times 30 \mathrm{~cm}$ in $2 \times 2$ sized plots (Mengesha and Tesfaye, 2015). The experiment was performed using a randomized block design (RBD) with three replicates. The samples were treated with the recommended dose (100\%) of 100,60, and $50 \mathrm{~kg} \mathrm{ha}^{-1}$ NPK (Mirzaei et al., 2007).

For the greenhouse experiments, the cultivation order was arranged in RBD in three replicates, with six types of organic components: manure (cattle, chicken, and goat) and peat (native and imported) from February 2016 to July 2016. First, soil samples in the field were collected from the topsoil layer $(20 \mathrm{~cm})$ in Taşköprü and mixed with other organic manures. Second, the soil mixtures (the soil sample and organic manures) were placed into 40 x 50 diameter pots, with a total of $5000 \mathrm{~g}$, as shown in Table 1. Homogeneous big sized garlic cloves were planted in triplicates, with 6-8 cloves and nine tubes used in each replica (Table 1). The cloves were planted in the soil mixture, such that the ends of the cloves and bulbs were visible on the soil surface (Vural et al., 2000). Irrigation 
of the garlic samples was performed twice a week with tap water according to the water-holding capacity of each pot until the seedling had 5-6 leaves. Application of 50\% water restriction to the garlic samples started when the seedlings reached the 5-6 leaf stage. They were kept in the greenhouse with an average temperature of $26 \pm 2^{\circ} \mathrm{C}$ and $65-70 \%$ humidity. Water given to the samples was estimated based on the water-holding capacity of the pots and values determined for each group were given in Table 1.

Table 1. Doses of soil mixtures where Taşköprü garlic samples were cultivated and amount of water to be applied for each group (50\% water shortage).

Çizelge 1. Taşköprü sarımsak örneklerinin ekildiği toprak karışımlarının dozları ve su miktarları (\%50 eksikliği).

\begin{tabular}{|c|c|c|c|c|c|c|c|c|}
\hline Groups & Control & $\begin{array}{l}\text { FS } \\
\text { Field soil }\end{array}$ & $\begin{array}{l}\text { IP } \\
\text { Imported } \\
\text { peat }\end{array}$ & $\begin{array}{l}\text { NP } \\
\text { Native } \\
\text { peat }\end{array}$ & Cattle & Goat & Chicken & $\begin{array}{l}\text { Water, } \\
\text { ml }\end{array}$ \\
\hline Control & & - & - & - & - & - & - & 270 \\
\hline FS & - & $5000 \mathrm{~g}$ & - & - & - & - & - & 135 \\
\hline FS-IPT & $3000 \mathrm{~g}$ & & $2000 \mathrm{~g}$ & & & & & 140 \\
\hline FS-NPT & $3000 \mathrm{~g}$ & & & $2000 \mathrm{~g}$ & & & & 140 \\
\hline FS-CATTLE & $3000 \mathrm{~g}$ & & & $1000 \mathrm{~g}$ & $1000 \mathrm{~g}$ & & & 140 \\
\hline $\begin{array}{l}\text { FS-CATTLE- } \\
\text { NPT }\end{array}$ & $3000 \mathrm{~g}$ & & $1000 \mathrm{~g}$ & & $1000 \mathrm{~g}$ & & & 145 \\
\hline $\begin{array}{l}\text { FS-GOAT- } \\
\text { NPT }\end{array}$ & $3000 \mathrm{~g}$ & & & $1000 \mathrm{~g}$ & & $1000 \mathrm{~g}$ & & 140 \\
\hline $\begin{array}{l}\text { FS- } \\
\text { CHICKEN- } \\
\text { GOAT } \\
\text { FS- }\end{array}$ & $2000 \mathrm{~g}$ & & & $1000 \mathrm{~g}$ & & $1000 \mathrm{~g}$ & $1000 \mathrm{~g}$ & 140 \\
\hline $\begin{array}{l}\text { CHICKEN- } \\
\text { IPT }\end{array}$ & $3000 \mathrm{~g}$ & & & $1000 \mathrm{~g}$ & & & $1000 \mathrm{~g}$ & 140 \\
\hline $\begin{array}{l}\text { FS-CATTLE- } \\
\text { GOAT }\end{array}$ & $2000 \mathrm{~g}$ & & & & $1000 \mathrm{~g}$ & $1000 \mathrm{~g}$ & $1000 \mathrm{~g}$ & 145 \\
\hline
\end{tabular}

Control: only soil in the field in Taşköprü district of Kastamonu.

To perform chemical analysis on fresh leaves of garlic samples, fully developed healthy leaves were collected from seedlings exposed to drought for 4 weeks. All analysis was done with fresh leaf tissue in triplicate. Application of $50 \%$ water stress to the garlic seedling was stopped before harvest when the leaves turn yellow and begin to twist. The mature bulbs were harvested when the top leaves were dried completely with a notable yellow colouration. The garlic samples were collected in the second week of July, 2016. All samples were dried in a place that is not exposed to sunlight (carton paper) for 12-13 days (Francois, 1994). Ten mature bulbs were randomly chosen from each soil mixture to determine the fresh weight of bulb $(\mathrm{g})$, as well as the polar and equatorial diameter of bulbs $(\mathrm{cm})$ per plant. For the fresh weight of bulbs, ten samples were weighed using an electronic weighing machine. The polar and equatorial diameter of bulbs $(\mathrm{cm})$ was estimated with a millimeter ruler.

Table 2. Properties of organic manures and field soil used in garlic cultivation.

Çizelge 2. Sarımsak ekiminde kullanılan toprak karışımlarının bazı özellikleri.

\begin{tabular}{lllllll}
$\begin{array}{l}\text { Nutrients of } \\
\text { Soils }\end{array}$ & Cattle & Chicken & GOAT & IPT & NPT & $\begin{array}{l}\text { Field soil } \\
\text { (control) }\end{array}$ \\
\hline$\% \mathrm{~N}$ & & & & & & 0.44 \\
$\% \mathrm{C}$ & 0.36 & 1.74 & 0.78 & 15 & 14 & 24.44 \\
$\% \mathrm{P}$ & 28.31 & 34.32 & 35.22 & 33.42 & 35.28 & 0.86 \\
$\mathrm{pH}$ & 0.24 & 1.58 & 0.34 & 10 & 10 & 6.76 \\
$\mathrm{mg} \mathrm{Fe} \mathrm{kg}$ & & 6.76 & 7.08 & 6.44 & 6.32 & 34960 \\
$\mathrm{mg} \mathrm{Zn} \mathrm{kg}{ }^{-1}$ & 88.74 & 144.56 & 124.46 & 2088 & 2046 & 459.42 \\
$\mathrm{mg} \mathrm{Mn} \mathrm{kg}{ }^{-1}$ & 43.34 & 46.34 & 88.46 & 108.22 & 116.44 & 459.42 \\
\hline
\end{tabular}

Soil samples to levels of $20 \mathrm{~cm}$ taken from Taşköprü and organic manures were air-dried, sieved, and used in elemental analysis at the Central Research Laboratory of Kastamonu University, which is shown in Table 2. The N, C, P, K of fertilizer used were $0.36-15 \%, 28.31-35.28 \%, 0.24-10 \%$ and $0.84-20 \%$, respectively. Other microelements were 88.74-34960 mg Fe kg-1, 43.34-88.68 $\mathrm{mg} \mathrm{Zn} \mathrm{kg}^{-1}$, and 78.36-459.42 $\mathrm{mg} \mathrm{Mn} \mathrm{kg}^{-1}$, respectively. The pH level of soils ranged from 6.32 to 7.17 (Table 2). 


\section{Chemical Analyses}

To determine the chlorophyll content of garlic leaves, $0.5 \mathrm{~g}$ of the fresh leaf was crushed in liquid nitrogen and homogenized by adding $10 \mathrm{ml}$ of $80 \%$ acetone in an ice bath (Lichtenthaler, 198). The mixture was centrifuged for 10 minutes at 3,000 rpm, and triplicate spectrophotometric (Shimadzu UV-260) readings of the supernatants noted were recorded at values of 652 and 450 . For $\beta$-carotene and lycopene content, the fresh samples and cloves were extracted with acetone-hexane (4:6) at once, then the optical density of the supernatant at $663 \mathrm{~nm}, 645 \mathrm{~nm}$, $505 \mathrm{~nm}$, and $453 \mathrm{~nm}$ was measured via a spectrophotometer at the same time. The concentrations of $\beta$-carotene $(\beta c)$ and lycopene (Ly) in the garlic homogenate (in $\mathrm{mg}$ per $100 \mathrm{ml}$ ) were estimated spectrophotometrically using the following equations (Nagata and Yamashita, 1992):

$$
\beta c=0.216 \times A 1-1.22 \times A 2-0.304 \times A 3+0.452 \times A 4
$$

Where; $\beta c=\beta$-Carotene in $100 \mathrm{ml} \mathrm{A} 1=\mathrm{A} 663 ; \mathrm{A} 2=\mathrm{A} 645 ; \mathrm{A} 3=\mathrm{A} 505 ; \mathrm{A} 4=\mathrm{A} 453$

$$
\begin{aligned}
& \text { Ly }=-0.0458 \times \mathrm{A} 1+0.204 \times \mathrm{A} 2+0.372 \times \mathrm{A} 3-0.0806 \times \mathrm{A} 4 \\
& \text { Where; Ly =Lycopene in } 100 \mathrm{ml} \mathrm{A} 1=\mathrm{A} 663 ; \mathrm{A} 2=\mathrm{A} 645 ; \mathrm{A} 3=\mathrm{A} 505 ; \mathrm{A} 4=\mathrm{A} 453
\end{aligned}
$$

The Bates method (1973) was used to estimate the proline content of the leaves and cloves, and the Bradford method (1976) was used to measure the soluble protein content of leaves and cloves. The total free amino acid content of both garlic parts was measured following the method of Moore and Stein (1948). $500 \mathrm{mg}$ sample was boiled in $10 \mathrm{ml}$ of $80 \%$ ethanol. Homogenate was centrifuged at $3500 \mathrm{~g}$ for $15 \mathrm{~min}$ and the clear supernatant was taken. Then it was completed to $10 \mathrm{ml}$ with ethanol. $1 \mathrm{ml}$ of extract was put into $25 \mathrm{ml}$ tube and $0.1 \mathrm{~N} \mathrm{NaOH}$ with methyl red and $1 \mathrm{ml}$ of ninhydrin reagent was added. Then, the mixture was incubated for $20 \mathrm{~min}$. Afterwards, 5 $\mathrm{ml}$ of ninhydrin reagent was put again and it was cooled in an ice bath. After completing with distilled water to $25 \mathrm{ml}$, the absorbance was read at $570 \mathrm{~nm}$. The standard was prepared by glycine and total free amino acid content was expressed as $\mathrm{mg} / \mathrm{g}$. The total phenolic amount was performed following the Folin-Ciocalteu method via spectrophotometric (Singleton et al., 1999). Total flavonoid measurement was done spectrophotometrically (Kumaran and Karunakaran, 2006).

The level of lipid peroxidation of the leaf and cloves were determined and expressed as MDA (malondialdehyde) content following the method of Çakmak and Horst (1991). The $\mathrm{H}_{2} \mathrm{O}_{2}$ (hydrogen peroxide) concentration was determined according to the method of (Velikova et al., 2000). The pyruvic acid content was determined via the colourimetric method following Schwimmer and Weston (1961). The total soluble carbohydrate was estimated by spectrophotometry at $620 \mathrm{~nm}$ following the Antron Method (McCready et al., 1950). Glucose and sucrose contents of leaves and cloves were measured following the Anthron Method by spectrophotometry at $630 \mathrm{~nm}$ for glucose and $620 \mathrm{~nm}$ for sucrose (Handel, 1968). To determine the enzyme activities of cloves, $0.5 \mathrm{~g}$ of the fresh leaf was crushed in liquid nitrogen and then homogenized with $5 \mathrm{ml}$ of 50 $\mathrm{mM}(\mathrm{pH}=7.6) \mathrm{KH} 2 \mathrm{PO} 4(\mathrm{pH}=7)$ buffered (potassium phosphate) solution containing $0.1 \mathrm{mM}$ Na-EDTA (SodiumEthylene Diamine Tetra Acetic acid). The mixtures were centrifuged for 10 minutes at $10.000 \mathrm{~g}$ and $4^{\circ} \mathrm{C}$. Enzyme activities in this supernatant were estimated. APX (ascorbate peroxidase) was determined following the method of Nakano and Asada (1981) by measuring the oxidation rate of ascorbate at $290 \mathrm{~nm}\left(\mathrm{E}=2.8 \mathrm{mM} \mathrm{cm}^{-1}\right)$ and SOD (superoxide dismutase) enzyme activity was measured following the method of Çakmak and Horst (1991). The data were analyzed through one-way analysis of variance (ANOVA) to POINT OUT the effect of different organic soil samples on Taşköprü garlic yield and chemical composition of them, using SPSS statistical software (SPSS for Windows, Release 16).

\section{RESULTS AND DISCUSSION}

The amount of photosynthetic pigments of leaves has been estimated as an index for evaluation of the source. Therefore, a reduction in this amount can be considered as nonstomatal impressions in drought stress conditions (Hussein et al., 2018; Kibar, 2020). In this study, chlorophyll (Chl) and carotenoid content obtained from garlic seedling, which was cultivated in different organic manures mixtures, were given in Table 3 . There was a significant difference between the garlic samples that were cultivated on different soil mixtures $(\mathrm{p}<0.05)$. Chl a, Chl b, and total chlorophyll showed an increase in leaves under drought when compared to the control group. Chl a level in garlic leaves ranged from 0.091-0.160 mg, Chl b from 0.067-0.267 mg, and total chlorophyll from 0.158-0.415 mg. 
Table 3. The amount of photosynthetic pigment, flavonoid and total phenolic in Taşköprü garlic leaves under $50 \%$ drought. Çizelge 3. \%50 kuraklık altındaki Taşköprü sarımsağı yapraklarında fotosentetik pigmentler, toplam flavonoit ve toplam fenolik bileşim miktarları.

\begin{tabular}{|c|c|c|c|c|c|c|c|}
\hline Groups & $\begin{array}{l}\text { Chl a } \\
\text { mg g }^{-1}\end{array}$ & $\begin{array}{l}\text { Chl b } \\
\text { mg g }^{-1}\end{array}$ & $\begin{array}{l}\text { Total } \\
\text { Chlorophyll } \\
\text { mg g }^{-1}\end{array}$ & Chl a: Chl b & $\begin{array}{l}\text { Total } \\
\text { Carotenoid } \\
\text { mg g }^{-1} \\
\end{array}$ & $\begin{array}{l}\text { Flavonoid } \\
\mu \mathrm{g} \mathrm{g}^{-1}\end{array}$ & $\begin{array}{l}\text { Total } \\
\text { phenolic } \\
\text { mg g }^{-1} \\
\end{array}$ \\
\hline Control & $0.091 \pm 0.001 a^{*}$ & $0.067 \pm 0.001 a$ & $0.158 \pm 0.00 \mathrm{a} 1$ & $1.36 \pm 0.003 e$ & $10.76 \pm 0.02 a$ & $116.33 \pm 0.06 a$ & $23.17 \pm 0.06 c$ \\
\hline FS & $0.148 \pm 0.001 b$ & $0.267 \pm 0.001 \mathrm{~g}$ & $0.415 \pm 0.00 \mathrm{~h}$ & $0.55 \pm 0.001 a$ & $10.66 a \pm 0.01 a$ & $152.57 \pm 0.18 b$ & $10.77 a \pm 0.02 a$ \\
\hline FS-IPT & $0.159 \pm 0.001 d$ & $0.174 \pm 0.001 \mathrm{~g}$ & $0.333 \pm 0.00 \mathrm{~g} 1$ & $0.92 \pm 0.003 b$ & $15.74 \pm 0.02 c$ & $268.65 \pm 0.05 f$ & $25.32 \pm 0.02 d$ \\
\hline FS-NPT & $0.157 \pm 0.001 c$ & $0.078 \pm 0.00 \mathrm{~b} 1$ & $0.234 \pm 0.001 b$ & $2.03 \pm 0.005 h$ & $15.89 \pm 0.01 c$ & $202.99 \pm 0.11 d$ & $23.41 \pm 0.04 c$ \\
\hline FS-CATTLE & $0.160 \pm 0.001 d$ & $0.091 \pm 0.001 c$ & $0.251 \pm 0.001 c$ & $1.76 \pm 0.004 \mathrm{~g}$ & $13.20 \pm 0.01 b$ & $272.55 \pm 0.13 f$ & $14.80 \pm 0.03 b$ \\
\hline FS-CATTLE-NPT & $0.160 \pm 0.001 d$ & $0.105 \pm 0.001$ & $0.264 \pm 0.001 d$ & $1.53 \pm 0.002 f$ & $12.42 \pm 0.02 b$ & $182.22 \pm 0.09 c$ & $27.58 \pm 0.03 e$ \\
\hline FS-GOAT-NPT & $0.158 \pm 0.001 c$ & $0.123 \pm 0.001 \mathrm{e}$ & $0.281 \pm 0.001 \mathrm{e}$ & $1.29 \pm 0.003 d$ & $12.78 \pm 0.01 b$ & $238.94 \pm 0.34 \mathrm{e}$ & $21.93 \pm 0.05 c$ \\
\hline $\begin{array}{l}\text { FS-CHICKEN- } \\
\text { GOAT }\end{array}$ & $0.157 \pm 0.001 c$ & $0.142 \pm 0.001 f$ & $0.298 \pm 0.001 f$ & $1.10 \pm 0.001 \mathrm{c}$ & $13.06 \pm 0.02 b$ & $243.38 \pm 0.05 e$ & $20.13 \pm 0.02 c$ \\
\hline FS-CHICKEN-IPT & $0.160 \pm 0.001 d$ & $0.102 \pm 0.001 d$ & $0.262 \pm 0.00 \mathrm{~d}$ & $1.58 \pm 0.003 f$ & $13.19 \pm 0.01 b$ & $314.60 \pm 0.05 \mathrm{~g}$ & $26.21 \pm 0.02 d$ \\
\hline $\begin{array}{l}\text { FS-CATTLE- } \\
\text { GOAT }\end{array}$ & $0.155 \pm 0.001 c$ & $0.145 f \pm 0.001$ & $0.300 \pm 0.001 f$ & $1.07 c \pm 0.002$ & $13.84 \pm 0.01 b$ & $208.97 \pm 0.04 d$ & $31.79 \pm 0.03 f$ \\
\hline F. & 32654.20 & 44876.88 & 32703.80 & & 2742.64 & 366502.12 & 168.84 \\
\hline Sig. & $<0.001$ & $<0.001$ & $<0.001$ & $<0.001$ & $<0.001$ & $<0.001$ & $<0.001$ \\
\hline
\end{tabular}

*Means within a group that has a different small letter are significantly different from each other. $\mathrm{P}<0.01$. Chl a:chlorophyll a; Chl b:chlorophyll b; Chl a:Chl b:ratio of Chla to Chl b.

When compared to the control samples $(0.091 \mathrm{mg})$, the highest $\mathrm{Chl}$ a was estimated in FS-CATTLE and FSCATTLE-NPT samples $(0.160 \mathrm{mg})$, while the highest $\mathrm{Chl} b$ and total chlorophyll were estimated in samples of FS and FS-IPT $(0.415-0.333 \mathrm{mg})$. Although the ratio of $\mathrm{Chl} a$ to $\mathrm{Chl} b$ reduced in FS and FS-IPT samples when compared to the control, the ratio was increased in the other samples. As observed in Table 3, drought induced carotenoid accumulation when compared to the control, except in FS samples. In general, the estimated values of pigments in this study agree with those cited in the literature, in which the concentration of chlorophyll and carotenoid increases in the tolerant species exposed to water deficiency (Hancl and Cebecl, 2014; Badran, 2015; Husseind and El-Faham, 2018). Similarly, Kıran (2019) found that chlorophyll and carotenoid level in lettuce leaves grown in vermiculite under drought stress were higher when compared to the control plants. Kibar (2018) found that chlorophyll content in lettuce was higher in vermicomposting applications than that of a control application, which was compatible with our findings. In this study, a high level of photosynthetic pigments in stressed garlic seedlings was associated with improvement of nitrogen, mineral, the water content of the soil, as well as organic manures (Wang et al., 2017; Amiri et al., 2017). Nitrogen is generally considered to be effective on chlorophyll synthesis in cultivated leafy species, especially in winter (Kopsell et al., 2007; Rambo et al., 2010).

In addition to the pigments, green leaves, non-enzymatic antioxidant (secondary metabolites) (Zoratti et al., 2014; Türk and Şen, 2020), soluble nitrogenous compounds (proline and protein), and sugar (glucose and sucrose) (Gulen et al., 2018) are molecules responsible for tolerance of plants to drought and other stresses in grown conditions (Garcia et al., 2014; Wang et al., 2017). As shown in Table 3, the amount of flavonoid in garlic seedlings was between 10.66 and $15.89 \mathrm{mg}$, whereas the total phenolic concentration was between 10.77 and $31.90 \mathrm{mg}$. The highest level of flavonoid $(314.60 \mu \mathrm{g})$ and total phenolic $(31.79 \mathrm{mg})$ was recorded with FS-CHICKEN-IPT and FS-CATTLE-GOAT samples. While the amount of flavonoid increased in all groups compared to control, the total phenolic molecules in FS and FS-CATTLE samples decreased to very low levels. Water shortage caused a decrease in the amount of proline, protein, glucose, and total soluble carbohydrate level of garlic seedling, which are the most important osmolytes that play a role in turgor and osmotic regulation in cells in response to drought (Garcia et al., 2014; Hancl and Cebei, 2015; Amiri et al., 2017).

However, proline concentration was high with FS-GOAT-NPT, sucrose was high with FS-CATTLE and FSCATTLE-GOAT samples, but MDA and $\mathrm{H}_{2} \mathrm{O}_{2}$ were elevated only in FS samples (Table 4). These findings support the previous results that the content of proline, protein, glucose, sucrose, and carbohydrate are lower under water restriction, but the amount of MDA and $\mathrm{H}_{2} \mathrm{O}_{2}$ is higher (Rahbarian et al., 2011; Gulen et al., 2017). The low osmolytes in garlic seedlings have been associated with the use of these compounds to prevent reactions that induce the accumulation of MDA and $\mathrm{H}_{2} \mathrm{O}_{2}$ molecules, which can be stimulated to accumulate in the cell by the combined effect of drought and nitrogen-rich soil mixtures (Table 4). As a matter of fact, the high amount of flavonoid and carotenoids in garlic samples strengthens this result (Riahi and Hdider, 2013; Edreva et al., 2015). 
Table 4. The amount of proline, protein, $\mathrm{MDA}, \mathrm{H}_{2} \mathrm{O}_{2}$, glucose, sucrose and total carbohydrate concentrations in Taşköprü garlic leaves under drought.

Çizelge 4. Kurak stresi altındaki Taşköprü sarımsağı örneklerinin yapraklarında prolin, protein, $\mathrm{MDA}, \mathrm{H}_{2} \mathrm{O}_{2}, g l i k o z$, sukroz ve toplam karbohidat miktarları.

\begin{tabular}{|c|c|c|c|c|c|c|c|}
\hline Groups & $\begin{array}{l}\text { Proline } \\
\boldsymbol{\mu m o l ~}^{-1}\end{array}$ & $\begin{array}{l}\text { Protein } \\
\mathbf{m g ~ g}^{-1}\end{array}$ & $\begin{array}{l}\text { MDA } \\
\mu \mathrm{mol} \mathbf{g}^{-1}\end{array}$ & $\begin{array}{l}\mathrm{H}_{2} \mathrm{O}_{2} \\
\mu \mathrm{mol} \mathbf{g}^{-1}\end{array}$ & $\begin{array}{l}\text { Glucose } \\
\text { mg g }^{-1}\end{array}$ & $\begin{array}{l}\text { Sucrose } \\
\text { mg g }^{-1}\end{array}$ & $\begin{array}{l}\text { Soluble } \\
\text { carbohydrate } \\
\%\end{array}$ \\
\hline Control & $5.39 \pm 0.06 d^{*}$ & $98.79 \pm 0.09 d$ & $192.49 \pm 0.25 f$ & $126.20 \pm 0.06 \mathrm{~g}$ & $131.65 \pm 0.01 c$ & $113.78 \pm 0.38 c$ & $65.82 \pm 0.05 c$ \\
\hline FS & $4.05 \pm 0.04 c$ & $60.30 \pm 0.11 a$ & $199.26 \pm 0.07 f$ & $268.35 \pm 0.06 h$ & $79.96 \pm 0.02 a$ & $67.58 \pm 0.01 b$ & $39.98 \pm 0.08 a$ \\
\hline FS-IPT & $2.36 \pm 0.20 \mathrm{a}$ & $81.30 \pm 0.02 c$ & $42.43 \pm 0.08 b$ & $113.89 \pm 0.06 f$ & $79.33 \pm 0.01 a$ & $67.37 \pm 0.09 b$ & $39.66 \pm 0.04 a$ \\
\hline FS-NPT & $2.46 \pm 0.14 a$ & $85.59 \pm 0.05 d$ & $52.88 \pm 0.05 d$ & $58.87 \pm 0.06 a$ & $82.68 \pm 0.06 \mathrm{~b}$ & $67.19 \pm 0.09 b$ & $41.34 \pm 0.29 b$ \\
\hline FS-CATTLE & $2.85 \pm 0.21 b$ & $89.74 \pm 0.04$ & $28.69 \pm 0.09 a$ & $65.38 \pm 0.08 b$ & $80.56 \pm 0.01 a$ & $132.73 \pm 0.03 d$ & $40.28 \pm 0.04 a$ \\
\hline $\begin{array}{l}\text { FS-CATTLE- } \\
\text { NPT }\end{array}$ & $2.19 \pm 0.27 a$ & $87.26 \pm 0.40 c$ & $45.26 \pm 0.05 c$ & $110.47 \pm 0.03 f$ & $79.78 \pm 0.01 a$ & $67.69 \pm 0.04 b$ & $39.89 \pm 0.04 a$ \\
\hline $\begin{array}{l}\text { FS-GOAT- } \\
\text { NPT } \\
\text { FS- }\end{array}$ & $5.42 \pm 0.26 d$ & $79.15 \pm 0.03 c$ & $40.65 \pm 0.18 b$ & $78.95 \pm 0.02 c$ & $79.47 \pm 0.05 a$ & $67.05 \pm 0.16 b$ & $39.73 \pm 0.23 a$ \\
\hline $\begin{array}{l}\text { CHICKEN- } \\
\text { GOAT } \\
\text { FS- }\end{array}$ & $3.32 \pm 0.15 b$ & $90.06 \pm 0.02 d$ & $114.65 \pm 0.10 \mathrm{e}$ & $125.48 \pm 0.03 g$ & $81.42 \pm 0.01 a$ & $111.42 \pm 0.06 c$ & $40.71 \pm 0.04 a$ \\
\hline $\begin{array}{l}\text { CHICKEN- } \\
\text { IPT }\end{array}$ & $4.34 \pm 0.06 c$ & $90.76 \pm 0.02 d$ & $35.30 \pm 0.06 \mathrm{~b}$ & $98.40 \pm 0.06 \mathrm{e}$ & $79.80 \pm 0.10 a$ & $63.67 \pm 0.01 a$ & $39.90 \pm 0.49 a$ \\
\hline $\begin{array}{l}\text { FS-CATTLE- } \\
\text { GOAT }\end{array}$ & $4.76 \pm 0.04 c$ & $71.80 \pm 0.08 b$ & $30.79 \pm 0.05 a$ & $84.65 \pm 0.03 d$ & $81.58 \pm 0.01 a$ & $146.27 \pm 0.02 \mathrm{e}$ & $40.79 \pm 0.04 a$ \\
\hline $\mathrm{F}$ & 5242.28 & 10699.86 & 401372.42 & 115757.47 & 14629.69 & 4895.96 & 31648.20 \\
\hline Sig. & $<0.001$ & $<0.001$ & $<0.001$ & $<0.001$ & $<0.001$ & $<0.001$ & $<0.001$ \\
\hline
\end{tabular}

*Means within a group that has a different small letter are significantly different from each other. $\mathrm{P}<0.01$.

\section{Bulbs Yield, Cloves and Chemicals}

As shown in Table 5, bulb yield parameters, such as number, average bulb weight, individual bulb weight, diameter, length and width of the bulb, and clove number were influenced with the soil mixtures under drought condition. The maximum bulb number of $34,28,27$, and 26 were recorded with FS-NPT-FS-CATTLE, FS-CHICKENGOAT, and FS-IPT, but the poorest value of it was noticed with FS-CATTLE-NPT and FS-CHICKEN-IPT as 17 and 19, respectively (Table 5 ).

Also, individual bulb weight was found to be higher than control, while length and diameter of bulbs were recorded as low in the first three samples coded as FS, FS-IPT, and FS-NPT (Table 5). The maximum number of cloves were noted in FS-CHICKEN-IPT and FS-CATTLE-GOAT samples $(9.27,9.12)$, whereas the lowest number was recorded in FS-NPT, FS-IPT, and FS samples as 3.77, 3.84, and 3.86, respectively (Table 5).

Table 5. The effects of $50 \%$ drought on bulb yield of Taşköprü garlic grown different soil mixture.

Çizelge 5. Farklı toprak karışımlarında yetişen Taşköprü sarımsağında \%50 kuraklık uygulamasının baș verimine etkisi.

\begin{tabular}{|c|c|c|c|c|c|}
\hline \multirow[b]{2}{*}{ Groups } & \multirow[b]{2}{*}{ Number } & \multicolumn{2}{|c|}{ Bulb } & \multirow[b]{2}{*}{$\begin{array}{l}\text { Width } \\
(\mathrm{cm})\end{array}$} & \multirow{2}{*}{$\begin{array}{l}\text { Clove } \\
\text { Number }\end{array}$} \\
\hline & & $\begin{array}{l}\text { Fresh weight } \\
\text { (g) }\end{array}$ & $\begin{array}{l}\text { Length } \\
\text { (cm) }\end{array}$ & & \\
\hline Control & $20 \pm 0.30 b^{*}$ & $10.71 \pm 0.29 b$ & $1.89 \pm 0.13 a b$ & $2.38 \pm 0.15 b$ & $4.44 \pm 0.70 \mathrm{~b}$ \\
\hline FS & $27 \pm 0.26 \mathrm{e}$ & $9.34 \pm 0.78 b$ & $1.72 \pm 0.08 a$ & $1.68 \pm 0.99 a$ & $3.86 \pm 0.99 a$ \\
\hline FS-IPT & $26 \pm 0.27 e$ & $9.87 \pm 0.31 b$ & $1.72 \pm 0.10 \mathrm{a}$ & $1.84 \pm 0.13 a$ & $3.84 \pm 0.63 a$ \\
\hline FS-NPT & $34 \pm 0.45 e$ & $10.38 \pm 0.16 b$ & $1.79 \pm 0.09 a$ & $2.14 \pm 0.15 b$ & $3.77 \pm 0.64 a$ \\
\hline FS-CATTLE & $28 \pm 0.27 d$ & $10.55 \pm 0.29 b$ & $1.93 \pm 0.12 a b$ & $1.84 \pm 0.10 a$ & $5.35 \pm 0.82 b c$ \\
\hline FS-CATTLE-NPT & $17 \pm 0.22 a$ & $14.23 \pm 1.49 b$ & $2.15 \pm 0.07 \mathrm{~b}$ & $2.57 \pm 0.07 c$ & $7.13 \pm 0.88 c$ \\
\hline FS-GOAT-NPT & $23 \pm 0.25 c$ & $15.15 \pm 0.85 c$ & $2.13 \pm 0.07 b$ & $2.61 \pm 0.09 c$ & $7.21 \pm 0.88 c$ \\
\hline FS-CHICKEN-GOAT & $28 \pm 0.27 d$ & $16.32 \pm 0.43 c$ & $2.16 \pm 0.13 b$ & $2.85 \pm 0.13 d$ & $8.65 \pm 1.08 d$ \\
\hline FS-CHICKEN-IPT & $19 \pm 0.22 b$ & $21.88 \pm 0.96 \mathrm{e}$ & $2.14 \pm 0.04 a$ & $2.92 \pm 0.16 d$ & $9.27 \pm 1.06 \mathrm{e}$ \\
\hline FS-CATTLE-GOAT & $20 \pm 0.22 b$ & $19.25 \pm 1.22 d$ & $2.82 \pm 0.16 c$ & $2.56 \pm 0.11 \mathrm{c}$ & $9.15 \pm 0.63 e$ \\
\hline $\mathrm{F}$ & 28.88 & 28.86 & 8.715 & 11.272 & 83.823 \\
\hline Sig. & $<0.0001$ & $<0.0001$ & $<0.0001$ & $<0.0001$ & $<0.0001$ \\
\hline
\end{tabular}

*Means within a group that has a different small letter are significantly different from each other. $\mathrm{P}<0.01$.

Based on the yield data, the drought resistance of FS-CATTLE-GOAT, FS-CHICKEN-GOAT, FS-CATTLE, and FSGOAT-NPT samples were found to be higher than control, but FS, FS-IPT, and FS-NPT samples were observed to be susceptible (Alphonse et al., 2015; Badran, 2015). The presence of goat and chicken manures in the groups with the highest measured values in garlic bulbs indicated that these soil mixtures make a significant contribution 
toward overcoming drought stress (Daba et al., 2018; Doğan et al., 2020). Results of this study have confirmed the results of Adewale et al. (2011) and Acharya and Kumar (2018) who revealed that organic fertilizers, such as poultry manure, sheep/goat manure, and cattle manures significantly enhanced the yield of garlic in terms of bulb weight, diameter, and clove number. Similarly, Kibar (2018) found that vermicompost applications have positive effects on plant growth parameters such as plant height, plant wet weight, plant dry weight and number of marketable leaves in lettuce. Other studies have revealed that organic manure can provide good soil fertility, such as rich nutrient, water-holding capacity, and aerobic conditions for plant growth and productivity, depends on manure types and doses, as well as season and genotype (Clautildea et al., 2017; Abou-El magd et al., 2012; Can et al., 2019).

Photosynthesis products accumulate in the subsoil parts of garlic and participate in the substances by respiration and synthesis reactions, which will play crucial roles during the storage time and germination stages. All of them are essential for plant and human life, since they are involved in many functions, such as eliminating or alleviating biotic and abiotic stresses injuries (Jaleel et al., 2008; Alphonse et al., 2015).

In this study, the amount of $\beta$-carotene, lycopene, flavonoid, and total phenolic content of garlic bulbs were significantly ( $p \leq 0.05$ ) affected by the soil mixtures and drought (Table 6). The drought reduced the amount of $\beta$-carotene in the garlic cloves in all groups when compared to the control, but lycopene level increased in FSCATTLE-NPT, FS-GOAT-NPT, FS-CHICKEN-GOAT, and FS-CHICKEN-IPT samples and the flavonoid level in FSCHICKEN-GOAT, FS-CHICKEN-IPT, and FS-CATTLE-GOAT (Table 6). The highest lycopene was detected in FSCATTLE-IPT and FS-CHICKEN-GOAT samples (2.085-1.969 $\mu \mathrm{g})$ and maximum flavonoid was observed in FSCATTLE-GOAT and FS-CHICKEN-IPT samples (46.37-46.22 mg). Total phenolic content of samples varied between 33.82-56.62 $\mathrm{mg}$ and decreased in FS, FS-GOAT-NPT, and FS-CATTLE-NPT samples (33.2, 37.60, and $41.64 \mathrm{mg}$ ) when compared to control (42.56 mg) (Table 6). As seen in Table 6, the highest level of lycopene was produced by FS-CHICKEN-IPT and FS-CHICKEN-GOAT; the highest flavonoid was produced by FS-CATTLE-GOAT and FSCHICKEN-IPT, while total phenolic was produced by FS-IPT and FS-CATTLE-GOAT compared to the control. These results are in agreement with the results of other studies, which expressed enhanced non-enzymatic compounds with the application of organic manure types under drought. Zhang et al. (2016) showed that the application of mixed organic manure with $\mathrm{N}$ increased the level of total phenolic and flavonoid in tomato.

Table 6. The effects of $\% 50$ droughts on $\beta$-carotene, lycopene, total flavonoid, total phenolic, proline, protein and free amino acid concentrations in the cloves of Taşköprü garlic grown different soil mixture.

Çizelge 6. \%50 kuraklık uygulamasının farklı toprak karışımlarında yetişen Taşköprü sarımsak dişlerinde $\beta$-karoten, likopen, toplam flavonoit, toplam fenolik bileşik, prolin, protein ve serbest amino asit konsantrasyonları üzerine etkileri.

\begin{tabular}{|c|c|c|c|c|c|c|c|}
\hline Groups & $\begin{array}{l}\beta \text {-carotene } \\
\boldsymbol{\mu g ~ g}^{-1}\end{array}$ & $\begin{array}{l}\text { Lycopene } \\
\boldsymbol{\mu g ~ g}^{-1}\end{array}$ & $\begin{array}{l}\text { Flavonoid } \\
\mathrm{mg} \mathrm{g}^{-1}\end{array}$ & $\begin{array}{l}\text { Total } \\
\text { phenolic } \\
\text { mg g }^{-1}\end{array}$ & $\begin{array}{l}\text { Proline } \\
\mu_{\mathrm{mol}} \mathrm{g}^{-1}\end{array}$ & $\begin{array}{l}\text { Protein } \\
\text { mg g }^{-1}\end{array}$ & $\begin{array}{l}\text { Free amino } \\
\text { acid } \\
\mu \mathrm{mol} \mathrm{g}{ }^{-1}\end{array}$ \\
\hline Control & $0.81 \pm 0.004 h^{*}$ & $1.644 \pm 0.003 \mathrm{~g}$ & $40.36 c \pm 0.06 c$ & $42.56 \pm 0.14 c$ & $9.38 \pm 0.02 e$ & $83.61 c \pm 0.03 c$ & $13.12 \mathrm{a} \pm 0.04$ \\
\hline FS & $0.73 \pm 0.002 f$ & $1.184 \pm 0.001 d$ & $31.80 b \pm 0.06 b$ & $33.82 \pm 0.09 a$ & $9.64 \pm 0.03 e$ & $96.72 d \pm 0.16 d$ & $14.22 b \pm 0.18$ \\
\hline FS-IPT & $0.06 a \pm 0.003 a$ & $0.905 \pm 0.001 a$ & $23.22 a \pm 0.14 a$ & $62.47 \pm 0.12 f$ & $2.38 \pm 0.03 a$ & $102.24 \mathrm{e} \pm 0.23 \mathrm{e}$ & $16.44 c \pm 0.24$ \\
\hline FS-NPT & $0.06 \pm 0.001 a$ & $1.052 \pm 0.002 c$ & $21.66 a \pm 0.07 a$ & $45.14 \pm 0.06 d$ & $5.91 \pm 0.02 c$ & $85.16 c \pm 0.10 c$ & $12.32 \mathrm{a} \pm 0.13$ \\
\hline FS-CATTLE & $0.53 \pm 0.001 \mathrm{c}$ & $0.981 \pm 0.001 b$ & $31.08 b \pm 0.05 b$ & $48.82 \pm 0.21$ & $5.97 \pm 0.03 c$ & $75.61 b \pm 0.25 b$ & $14.46 b \pm 0.22$ \\
\hline $\begin{array}{l}\text { FS-CATTLE- } \\
\text { NPT }\end{array}$ & $0.33 \pm 0.001 b$ & $1.708 \pm 0.001 \mathrm{~h}$ & $23.93 a \pm 0.07 a$ & $41.64 \pm 0.17 b$ & $4.32 \pm 0.06 b$ & $80.13 c \pm 0.17 c$ & $14.28 b \pm 0.18$ \\
\hline $\begin{array}{l}\text { FS-GOAT- } \\
\text { NPT }\end{array}$ & $0.57 \pm 0.002 d$ & $1.552 \pm 0.002 f$ & $27.78 b \pm 0.11 b$ & $37.60 \pm 0.16 b$ & $7.22 \pm 0.02 d$ & $61.46 a \pm 0.16 a$ & $18.44 c \pm 0.18$ \\
\hline $\begin{array}{l}\text { FS-CHICKEN- } \\
\text { GOAT }\end{array}$ & $0.65 \pm 0.010 \mathrm{e}$ & $1.969 \pm 0.001$ & $44.33 d \pm 0.10 d$ & $43.69 \pm 0.14 c$ & $8.34 \pm 0.02 \mathrm{e}$ & $92.37 d \pm 0.22 d$ & $20.28 d \pm 0.21$ \\
\hline $\begin{array}{l}\text { FS-CHICKEN- } \\
\text { IPT }\end{array}$ & $0.68 \pm 0.00 \mathrm{e} 1$ & $2.085 \pm 0.001 i$ & $46.22 \mathrm{e} \pm 0.22 \mathrm{e}$ & $47.77 \pm 0.17 d$ & $8.20 \pm 0.01 \mathrm{e}$ & $64.24 a \pm 0.17$ & $20.24 d \pm 0.18$ \\
\hline $\begin{array}{l}\text { FS-CATTLE- } \\
\text { GOAT }\end{array}$ & $0.80 \pm 0.002 \mathrm{~g}$ & $1.350 \pm 0.002 d$ & $46.37 e \pm 0.15 e$ & $56.62 \pm 0.26 \mathrm{e}$ & $6.68 \pm 0.01 d$ & $92.65 d \pm 0.28$ & $22.56 \mathrm{e} \pm 0.24$ \\
\hline $\mathrm{F}$ & 12443.32 & 75967.51 & 7154.82 & 11982.53 & 10513.68 & 837.14 & 4466.45 \\
\hline Sig. & 0.000 & 0.000 & 0.000 & 0.000 & 0.000 & 0.000 & 0.000 \\
\hline
\end{tabular}

*Means within a group that has a different small letter are significantly different from each other. $\mathrm{P}<0.01$.

Alphonse et al. (2015) tested the effect of organic manures as vegetable waste, cattle dung, and inorganic fertilizer (NPK) in Solanum nigrum and they found that higher level of vitamin c, flavonoids, total phenolics, tannins, and saponins were produced by organic manure compared to NPK fertilizer. 
Garlic bulbs contain a different compatible compounds, such as nitrogen-containing compounds, including proline, free amino acid, soluble proteins, reduced soluble sugars, organic acid (pyruvate), and antioxidant enzymes, which are important for growth and development as building substances, energy sources, osmotic regulation, and even protection against the negative effects of drought stress (Jaleel et al., 2008; Salehi et al., 2016). It has been shown that these compounds are also very effective in preventing water loss, oxidation of bioactive chemicals, and tissue decay under the storage time of garlic (Azzini et al., 2014; Can et al., 2019).

In this study, the amount of proline decreased overall with drought, but showed a partial increase in FS samples and amino acid increased in all samples compared to control, except for the FS-NPT sample (Table 6). The highest amino acid was recorded in FS-CATTLE-GOAT, FS-CHICKEN-GOAT, and FS-CHICKEN-IPT samples as 22.56, 20.28, and $20.24 \mathrm{mg}$, respectively. Total soluble protein amount was lowest in FS-GOA-NPT and FS-CHICKEN-IPT (61.46$64.24 \mathrm{mg}$ ) samples when compared to the control $(83.61 \mathrm{mg})$, whereas it reached the highest value in FS-IPT and FS samples (102.24-96.72 mg) (Table 6).

The fact that water stress caused a decrease in the proline content while increasing the free amino acid level was associated with the use of proline to prevent water loss in garlic cloves (Mafakheri et al., 2010; Vidya vani et al., 2019). As a matter of fact, the general low MDA and pyruvate content of garlic cloves compared to the control confirms this idea (Table 7). Pyruvate, a key molecule of the Krebs cycle in respiratory reactions, is an important indicator of respiratory rate, which occurs easily under drought conditions (Gupta and Igamberdiev, 2016). MDA accumulates in cells as a result of enzymatic and non-enzymatic destruction of cellular membrane lipids-induced drought and $\mathrm{H}_{2} \mathrm{O}_{2}$ as a result of oxidative stress and may cause irreversible damage to the structures of organic molecules indispensable for cell viability (Smith and Dukes, 2013; Gulen et al., 2018).

Table 7. The effects of $\% 50$ drought on pyruvic acid, MDA, $\mathrm{H} 2 \mathrm{O} 2$, sucrose and soluble carbohydrate concentrations, and APX and SOD activities in the cloves of Taşköprü garlic.

Çizelge 7. \%50 kurak uygulamasının Taşköprü sarımsağı dişlerinde pürivik asit, MDA, H2O2, sukroz ve toplam karbohidrat konsantrasyonları ve APX ve SOD aktiviteleri üzerine etkileri.

\begin{tabular}{|c|c|c|c|c|c|c|c|c|}
\hline Groups & $\begin{array}{l}\text { Pyruvic } \\
\text { Acid } \\
\mu \mathrm{mol} \mathbf{g}^{-1}\end{array}$ & $\begin{array}{l}\text { MDA } \\
\mu_{\mathrm{mol}} \mathrm{g}^{-1}\end{array}$ & $\begin{array}{l}\mathrm{H}_{2} \mathrm{O}_{2} \\
\mu \mathrm{mol} \mathrm{g}\end{array}$ & $\begin{array}{l}\text { APX } \\
\text { EU mg } \\
\text { Protein }^{-1}\end{array}$ & $\begin{array}{l}\text { SOD } \\
\text { EU mg } \\
\text { Protein }^{-1}\end{array}$ & $\begin{array}{l}\text { Glucose } \\
\text { mg g}^{-1}\end{array}$ & $\begin{array}{l}\text { Sucrose } \\
\mathrm{mg} \mathrm{g}^{-1}\end{array}$ & $\begin{array}{l}\text { Total } \\
\text { Soluble } \\
\text { Carbohydra } \\
\text { te } \%\end{array}$ \\
\hline Control & $16.64 \pm 0.6 c^{*}$ & $\begin{array}{l}8.35 d \pm 0.01 \\
d\end{array}$ & $\begin{array}{l}21.46 \pm 0.22 \\
b\end{array}$ & $\begin{array}{l}2.33 \pm 0.002 \\
a\end{array}$ & $58.65 \pm 0.23 c$ & $\begin{array}{l}190.33 \pm 0.26 \\
c\end{array}$ & $\begin{array}{l}178.85 c \pm 0.07 \\
c\end{array}$ & $91.88 \pm 0.01 d$ \\
\hline FS & $16.88 \pm 0.14 d$ & $6.91 c \pm 0.01 c$ & $\begin{array}{l}40.21 \pm 0.12 \\
\mathrm{e}\end{array}$ & $\begin{array}{l}2.64 \pm 0.006 \\
b\end{array}$ & $49.56 \pm 0.22 b$ & $\begin{array}{l}157.66 \pm 0.17 \\
b\end{array}$ & $173.65 \pm 0.14 a$ & $87.78 \pm 0.01 c$ \\
\hline FS-IPT & $15.22 \pm 0.22 c$ & $\begin{array}{l}3.35 b \pm 0.01 \\
b\end{array}$ & $\begin{array}{l}12.46 \pm 0.19 \\
\text { a }\end{array}$ & $\begin{array}{l}2.35 \pm 0.020 \\
\text { a }\end{array}$ & $49.64 \pm 0.39 b$ & $\begin{array}{l}158.52 \pm 0.20 \\
b\end{array}$ & $175.81 \pm 0.12 b$ & $83.58 \pm 0.02 b$ \\
\hline FS-NPT & $15.68 \pm 0.14 c$ & $\begin{array}{l}2.42 a \pm 0.01 \\
a\end{array}$ & $\begin{array}{l}11.43 \pm 0.07 \\
\mathrm{a}\end{array}$ & $\begin{array}{l}2.95 \pm 0.010 \\
d\end{array}$ & $47.85 \pm 0.11 a$ & $\begin{array}{l}161.89 \pm 0.28 \\
b\end{array}$ & $169.32 \pm 0.14 a$ & $78.17 \pm 0.01 a$ \\
\hline $\begin{array}{l}\text { FS- } \\
\text { CATTLE }\end{array}$ & $18.26 \pm 0.18 d$ & $\begin{array}{l}4.22 b \pm 0.01 \\
b\end{array}$ & $\begin{array}{l}25.00 \pm 0.04 \\
b\end{array}$ & $\begin{array}{l}2.24 \pm 0.002 \\
a\end{array}$ & $49.78 \pm 0.06 b$ & $\begin{array}{l}155.80 \pm 0.28 \\
b\end{array}$ & $169.77 \pm 0.08 a$ & $84.48 \pm 0.02 b$ \\
\hline $\begin{array}{l}\text { FS- } \\
\text { CATTLE- } \\
\text { NPT }\end{array}$ & $18.34 \pm 0.17 d$ & $\begin{array}{l}5.42 b \pm 0.01 \\
b\end{array}$ & $\begin{array}{l}26.62 \pm 0.15 \\
c\end{array}$ & $\begin{array}{l}2.88 \pm 0.002 \\
c\end{array}$ & $59.84 \pm 0.08 c$ & $\begin{array}{l}184.82 \pm 0.08 \\
C\end{array}$ & $172.29 \pm 0.08 a$ & $84.90 \pm 0.02 b$ \\
\hline $\begin{array}{l}\text { FS- } \\
\text { GOAT- } \\
\text { NPT }\end{array}$ & $12.46 \pm 0.18 a$ & $\begin{array}{l}4.47 b \pm 0.01 \\
b\end{array}$ & $\begin{array}{l}31.76 \pm 0.06 \\
d\end{array}$ & $\begin{array}{l}2.75 \pm 0.005 \\
b\end{array}$ & $45.36 \pm 0.03 b$ & $\begin{array}{l}147.58 \pm 0.16 \\
a\end{array}$ & $178.52 \pm 0.14 b$ & $87.29 \pm 0.01 c$ \\
\hline $\begin{array}{l}\text { FS- } \\
\text { CHICKEN } \\
\text {-GOAT }\end{array}$ & $\begin{array}{l}12.64 \pm 0.22 a \\
b\end{array}$ & $\begin{array}{l}4.43 b \pm 0.01 \\
b\end{array}$ & $\begin{array}{l}39.52 \pm 0.12 \\
\mathrm{e}\end{array}$ & $\begin{array}{l}2.86 \pm 0.006 \\
c\end{array}$ & $66.78 \pm 0.06 d$ & $\begin{array}{l}159.83 \pm 0.11 \\
b\end{array}$ & $176.55 \pm 0.22 b$ & $86.40 \pm 0.02 b$ \\
\hline $\begin{array}{l}\text { FS- } \\
\text { CHICKEN } \\
\text {-IPT }\end{array}$ & $12.42 \pm 0.16 a$ & $5.34 b \pm 0.01$ & $\begin{array}{l}23.93 \pm 0.04 \\
b\end{array}$ & $\begin{array}{l}3.62 \pm 0.006 \\
\mathrm{e}\end{array}$ & $72.26 \pm 0.05 e$ & $\begin{array}{l}158.90 \pm 0.14 \\
b\end{array}$ & $175.32 \pm 0.13 a$ & $86.88 \pm 0.02 b$ \\
\hline $\begin{array}{l}\text { FS- } \\
\text { CATTLE- } \\
\text { GOAT }\end{array}$ & $16.22 \pm 0.22 d$ & $5.11 b \pm 0.01$ & $46.59 \pm 0.32 f$ & $\begin{array}{l}2.74 \pm 0.011 \\
b\end{array}$ & $\begin{array}{l}68.348 \pm 0.14 \\
e\end{array}$ & $\begin{array}{l}187.26 \pm 0.24 \\
c\end{array}$ & $174.11 \pm 0.01 a$ & $88.00 \pm 0.20 c$ \\
\hline $\mathrm{F}$ & 11213.68 & 4012888.34 & 116646.47 & 6314.24 & 6374.56 & 418.81 & 289.91 & 418.81 \\
\hline Sig. & $<0.001$ & $<0.001$ & $<0.001$ & 0.000 & 0.000 & 0.000 & 0.000 & 0.000 \\
\hline
\end{tabular}

*Means within a group that has a different small letter are significantly different from each other. $\mathrm{P}<0.01$.

The generally low MDA content in garlic samples may be related to the soil samples used, as well as the drought resistance. In previous studies, it has been shown in detail that organic manure mixed into the soil 
increases yield and quality in plant production by enriching the soil's organic matter composition, water-holding capacity, and mineral status (Adewale et al., 2011; Garcia et al., 2014; Can et al., 2019). Salehi et al. (2016) and Baddour et al. (2017) stated that proline, amino acid, and soluble protein increased with the application of organic manure types. According to variation of antioxidant enzymes, such as ascorbate peroxidase (APX) and superoxide dismutase (SOD) in this present investigation, APX activity reduced only in FS-CATTLE samples with respect to control, while SOD activity was found to be significantly higher in FS-CHICKEN-IPT, FS-CATTLE-GOAT, and FSCHICKEN-GOAT (Table 7). Considering the enzyme values, animal fertilizers increased the enzyme activities in garlic samples under drought by improving the nitrogen, mineral content, and water status of the soil. These values were similar to the results from Ahmed et al. (2010) and Abd El-Ghany (2007) who noted a significant increase in activities of enzymes, such as CAT, POD, and SOD in response to organic crop management in sorghum and wheat genotypes. Also, Siavoshi and Laware (2013) studied the role of soil mixtures with cow manure, poultry manure, rice straw, and husk on antioxidant enzymes activities of rice grain. Soluble carbohydrates, such as glucose, sucrose, fructose, and fructans, are the main reserved substances of garlic and onion bulbs (Bizuayehu et al., 2018; Burritt, 2019). Sugar profiles of the garlic samples are shown in Table 6. The results showed that the amount of glucose, sucrose, and total soluble sugars were significantly lower in all groups with respect to the control cloves (Table 6). In our opinion, the low sugar content in the garlic samples compared to the control is a strategy for the regulation of turgor and osmosis in garlic cloves, with the combined effect of soil mixtures and drought (Amiri et al., 2017). A certain amount of water loss observed in the garlic tissues after harvest prevents decay, loss of colour and weight and early sprouting during storage of the cloves (Rohkin Shalom et al., 2015; Lisciani et al., 2017).

\section{CONCLUSION}

This present study has demonstrated that the mixture of different organic manures, peat, and soil significantly increased the amount of photosynthetic pigment, carotenoid, and flavonoid in the garlic leaf samples under greenhouse conditions exposed to drought treatments seedling. Also, according to the results, the measurement of bulb weight, length, and diameter and also the amount of lycopene, flavonoid, total phenolic, the free amino acid of garlic cloves obtained from FS-CHICKEN-IPT, FS-CATTLE-GOAT, FS-CHICKEN-GOAT, and FS-GOAT-NPT was found to be higher compared to non-stressed samples. Moreover, the activities of APX (ascorbate peroxidase) and SOD (superoxide dismutase) were high, but MDA and pyruvate concentrations were low in these samples. These soil mixtures increased the resistance of Taşköprü garlic against drought application by $50 \%$, thus resulting in an increase in the head yield and the amount of bioactive components in the garlic. In contrast, soil mixtures of FS, FS-IPT, FS-NPT, and FS-CATTLE caused water to flow through the mixture, thus reducing drought stress tolerance. According to the results, it can be concluded that the mixture of the field soil with the chicken, goat, and cattle manures can be used to obtain higher yield and better chemical compound in the garlic production, which is underwater limitation areas and nutrient-deficient.

\section{CONFLICT OF INTEREST}

As an author, I declare that there is no conflict of interest in the planning, execution and writing of the article.

\section{DECLARATION OF AUTHOR CONTRIBUTION}

As the author, the planning, execution and writing of the articles was carried out by me.

\section{ACKNOWLEDGMENT}

This study has been conducted by virtue of the assistance provided through the KUBAP-01/2014-21 project.

\section{REFERENCES}

Abd El-Gha, H. M. (2007). Wheat production under water-limited sandy soil conditions using bio-organic fertilizer systems. Egyptian Journal of Agronomy, 29(1),17-27. 
Abou El-Magd, M. M., El-Shourbagy, T., \& Shehata, S. M. (2012). A comparative study on the productivity of four Egyptian garlic cultivars grown under various organic materials in comparison to conventional chemical fertilizer. Australian Journal of Basic and Applied Sciences, 6(3), 415-421.

Acharya, S., \& Kumar, H. (2018). Effect of some organic manure on growth and yield of garlic in greenhouse condition at cold desert high altitude Ladakh Region. Defence Life Science Journal, 3(2), 100-104.

Adewale, O. M., Adebayo, O. S., \& Fariyike, T. A. (2011). Effect of poultry manure on garlic (Allium Sativum L) production in Ibadan, South Western Nigeria Continental. Journal of Agricultural Science, 5(2), 7- 11.

Ahmed, O. H., Sumalatha G., \& Nik Muhamad, A. M. (2010). Use of zeolite in maize (Zea mays) cultivation on nitrogen, potassium and phosphorus uptake and use efficiency. International Journal of Physical Sciences, 5(15), 2393-2401.

Akça, H., Taban, N., Turan, M. A., Taban, S., Oudraogo, A. R., \& Türkmen, N. (2017). Türkiye'de sarımsak tarımı yapılan toprakların verimlilik durumu. Toprak Bilimi ve Bitki Besleme Dergisi, 5(2), 93-100.

Alphonse, J., Mary, L., \& Nithiya, T. (2015). Effect of organic and inorganic fertilizer on growth, phenolic compounds and antioxidant activity of Solanum nigrum L. World Journal of Pharmacy and Pharmaceutical Sciences, 4(5), 808-882.

Amiri, H., Ismaili, A., \& Hosseinzadeh, S. R. (2017). Influence of vermicompost fertilizer and water deficit stress on morphophysiological features of chickpea (Cicer arietinum L. cv. Karaj). Compost Science \& Utilization, 25, 152-165.

Azzini, E., Durazzo, A., Foddai, M. S., Temperini, O., Venneria, E., Valentini, S., \& Maiani, G. (2014). phytochemicals content in Italian garlic bulb (Allium sativum L) varieties. Journal of Food Research, 3(4), 26-32.

Baddour, A. G., Rashwan, E. M., \& El-Sharkawy, T. A. (2017). Effect of organic manure, antioxidant and proline on corn (Zea mays L.) grown under saline conditions. Environment Biodiversity and Soil Security, 1, 200-201.

Badran, A. E. (2015). Comparative analysis of some garlic varieties under drought stress conditions. Journal of Agricultural Science, $7(10), 271-280$

Bates, L. S., Waldern, R. P., \& Teare, I. D. (1973). Rapid determination of free proline for water-stress studies. Plant and Soil, 39, 205-207.

Bergmeyer, J., \& Grabl, M. (1983). Methoden der enzymatischen analyse [Methods of enzymatic analysis]. Akademie Verlag, 1, 190-302.

Bizuayehu, D., Kebede, W., Wassu, M., Bekele, A., \& Getachew, T. (2018). Duration of low temperature storage, clove topping and gibberellic acid on garlic sprouting and seedling vigor. African Journal of Food Agriculture Nutrition and Development, 18(2), 13420-13437.

Bradford, M. M. (1976). A rapid sensitive method for the quantitation of microprogram quantities of protein utilizing the principle of protein-dye binding'. Analytical Biochemistry 72, 248-254.

Burritt, D. J. (2019). Crop Plant Adaption to Climate Change and Extreme Environments. Encyclopedia of Food Chemistry. Academic Press, Oxford.

Cakmak, I. (1994). The activity of ascorbate-dependent $\mathrm{H}_{2} \mathrm{O}_{2}$-scavenging enzymes and leaf chlorosis are enhanced in magnesium and potassium deficient leaves. Journal Experimental Botany, 45, 1259-1266.

Can, B. A., Ünal, M., \& Can, O. N. (2019). The effects of different bat guano treatments on yield and quality in lettuce growing. International Journal of Agriculture and Wildlife Science, 5(1),18-24.

Çakmak, I., \& Horst, W. J. (1991). Effect of aluminium on lipid peroxidation, superoxide dismutase, catalase and peroxidase activities in root tips of soybean (Glycine max). Physiologia Plantarum, 83, 463-468.

Clautildea, M., Luciena, T. T., Eric, N., Abba, M., \& Hamadou, B. (2017). Field productivity of carrot (Daucus carota L.) in Adamawa Cameroon and chemical properties of roots according to chicken manure pretreatments and vivianite powder. Journal of Agriculture and Veterinary Science, 10(5),16-23.

Daba, G., Mulgeta, M., \& Ayaa, T. (2018). Effect of cattle manure on growth and yield of carrot (Daucus carrota L.) under Jimma condition. Indian Journal of Agricultural Research, 52 (2), 195-198.

Dikinya, O., \& Mufwanzala, N. (2010). Chicken manure-enhanced soil fertility and productivity: Effects of application rates. Journal of Soil Science and Environmental Management, 1(3), 46-54.

Doğan, S., Acıbuca, V., \& Doğan, Y. (2020). the effect and economic analysis of organic and ınorganic fertiliser applications on yield and quality of the 2 nd product corn varieties. International Journal of Agriculture and Wildlife Science, 6(39),592-604.

Duyar, H. (2014). Effect of green manure and poultry manure on yield and fruit quality in organic greenhouse tomato production. Journal of Agronomy, 20(1), 10-18. 
Edreva, A., Velikova V., Tsonev T., Dagnon S., Gürel A. L. \& Aktas L. (2015). Stressprotective role of secondary metabolites: Diversity of functions and mechanisms. General Applied of Plant Physiology, 34, 67-78.

Farouk, S. (2015). Improving growth and productivity of potato (Solanum tuberosum L.) by some biostimulants and lithovit with /or without boron. Journal of Agricultural Research, 45(6), 1871-1884.

Francois, L. E. (1994). Yield and quality response of salt-stressed Garlic. Hortscience, 29(11), 1314-1317.

Garcia, A. C., Santos, L. A., Izquierdo, F. G., Rumjanek, V. M., Castro, R. N., dos Santos, F. S., \& de Souza, L. G. A. (2014) . Potentialities of vermicompost humic acids to alleviate water stress in rice plants (Oryza sativa L). Journal of Geochemical Exploration, 136, 48-54.

Gulen, H., Kesici, M., Cetinkaya, C., \& Ergin, S. (2018). Proline and antioxidant enzyme activities in some strawberry cultivars under drought and recovery. Notulae Botanicae Horti Agrobotanici Cluj-Napoca, 46(2), 570-578.

Gupta, K. J., \& Igamberdiev, A. U. (2016). Reactive nitrogen species in mitochondria and their implications in plant energy status and hypoxic stress tolerance. Frontier in Plant Sciences, 24(7), 369.

Hancı, F., \& Cebeci, E. (2014). Investigation of proline, chlorophyll and carotenoids changes under drought stress in some onion (Allium Cepa L.) Cultivars. Turkish Journal of Agricultural and Natural Sciences, 2 (S),1449-1504.

Hancl, F., Cebecl, E. (2015). Comparison of salinity and drought stress effects on some morphological and physiological parameters in onion (Allium Cepa L.) during early growth phase. Bulgarian Journal of Agricultural Science, 21 (6), 12041210.

Handel, E. V. (1968). Direct micro determination of sucrose. Analytical Biochemistry, 22(2),280-283.

Hussein, M. M., \& El-Faham, S. Y. (2018). Chlorophyll, carotenoids pigments and growth of three onion cultivars as affected by saline water irrigation. Egyptian Journal of Agronomy, 40(3), 285-296.

Jaleel, C. A., Jayakumar, K., Chang-Xing, Z., \& Azooz, M. M. (2008). Effect of soil applied cobalt on activities of antioxidant enzymes in Arachis hypogaea. Global Journal of Molecular Sciences, 3(2), 42-45.

Kacar, B., Taban, S., Alpaslan, A., \& Fuleky, G. (1998). Zinc-Phosphorus Relationship in the Dry Matter Yield and the Uptake of $\mathrm{Zn}, \mathrm{P}, \mathrm{Fe}$ and Mn of Rice Plants (Oryza sativa L.) as Affected by the Total Carbonate Content of the Soil. Second International Zinc Symposium. Abstracts, pp, 20. October 2-3, Ankara-Turkey.

Kıran, S. (2019). Effects of vermicompost on some morphological, physiological and biochemical parameters of lettuce (Lactuca sativa var. crispa) under drought stress. Notulae Botanicae Horti Agrobotanici Cluj-Napoca, 47(2), 352-358.

Kibar, B. (2018). Determination of the interrelationships among plant properties, some quality properties and elements in lettuce. International Journal of Agriculture and Wildlife Science, 4(2), 149-160.

Kibar, B. (2020). Effects of microbial fertilizer application on germination and seedling growth in lettuce and white head cabbage. International Journal of Agriculture and Wildlife Science, 6(3), 389-398.

Kopsell, D. A., Kopsell, D. E., \& Curran-Celentano, J. (2007). Carotenoid pigments in kale are influenced by nitrogen concentration and form. Journal of the Science and Agriculture, 87, 900-907.

Kumaran, A., \& Karunakaran, R. J. (2006). Antioxidant and free radical scavenging activity of an aqueous extract of Coleus aromaticus. Food Chemistry, 97, 109-114.

Kurt, D., Yılmaz, A., \& Kınay, A. (2020). Effects of environmental variations on yield of oriental tobaccos. International Journal of Agriculture and Wildlife Science, 6(2), 310-324.

Lıchtenthaler, H. K. (1987). Chlorophyll and carotenoids: pigments of photosynthetic biomembranes. Methods in Enzymology, 148, 350-382.

Lisciani, S., Gambelli, L., Durazzo, A., Marconi, S., Camilli, E., Rossetti, C., Gabrielli, P., Aguzzi, A., Temperini, O, \& Marletta, L. (2017). Carbohydrates components of some Italian local landraces: Garlic (Allium sativum L.). Sustainability, 9(11), 19221927.

Mafakheri, A., Siosemardeh, A., Bahramnejad, B., Struik P. C., \& Sohrabi, Y. 2010. Effect of drought stress on yield, proline and chlorophyll contents in three chickpea cultivars. Australian Journal of Crop Science, 4(8), 50-585.

Mahmoody, M., Fahramand, M., Keykha, A., Noori, M., \& Rigi, K. (2014). Influence of green manure on increase cropping system sustainability. International Research Journal of Applied and Basic Sciences, 8(2), 253-256.

McCready, R., Guggolz, M. J., Silviera, V., \& Owens, H. S. (1950). Determination of starch and amylase in vegetables. Analytic Chemistry, 22, 1156-1158.

Mengesha, W., \& Tesfaye, A. (2015).Effect of spacing in incidence and severity of garlic rust (Puccinia allii) and bulb yield and related traits of garlic at eastern Ethiopia. Plant Pathology and Microbiology, 6(10), 314-317. 
Moore, S., \& Stein, W. H. (1948). Photometric method for use in the chromatography of amino acids. Journal of Biological Chemistry, 176(1), 367-388.

Nagata, M., \& Yamashita, I. (1992). Simple method for simultaneous determination of chlorophyll and carotenoids in tomato fruit. Nippon Shokuhin Kogyo Gakkaish, 39(10), 925-928.

Nakanao, Y., \& Asada K. (1981). Hydrogen peroxide is scavenged by ascorbate-specific peroxidase in spinach chloroplasts. Plant Cell Physiology, 22(5), 867-880.

Rahbarian, R., Khavari-Nejad, R., Ganjeali, A., Bagheri, A., \& Najafi, F. (2011). Drought stress effects on photosynthesis, chlorophyll fluorescence and water relations in tolerant and susceptible chickpea (Cicer arietinum L.). Acta Biologica Cracoviensia Butanica, 53(1).

Rambo, L., Ma, B. L., Xiong, Y., \& da Silvia P. 2010. Leaf and canopy optical characteristics as Crop-N-status indicators for field nitrogen management in corn. Journal of Plant Nutrition Soil Science, 173, 434-443.

Rekowska, E., \& Skupień, K. (2008). estimation of yield and chemical composition of winter garlic grown for bunch-harvest. Journal of Central European Agriculture, 9(4),711-714.

Riahi, A., \& Hdider, C. (2013). Bioactive compounds and antioxidant activity of organically grown tomato (Solanum lycopersicum L.) cultivars as affected by fertilization. Scientia Horticulturae, 151, 90-96.

Rohkin Shalom, S., Gillett, D., Zemach, H., Kimhi, S., Forer, I., Zutahy, Y., Tam, Y., Teper-Bamnolker, P., Kamenetsky, R., \& Eshel, D. (2015). Storage temperature controls the timing of garlic bulb formation via shoot apical meristem termination. Planta, 242, 951-962.

Salehi, A., Tasdighi, H., \& Gholamhoseini, M. (2016). Evaluation of proline, chlorophyll, soluble sugar content and uptake of nutrients in the German chamomile (Matricaria chamomilla L.) under drought stress and organic fertilizer treatments. Asian Pacific Journal of Tropical Biomedicine, 6(10),886-891.

Schwimmer, S., \& Weston, W. J. (1961). Enzymatic development of pyruvic acid in onion as a measure of pungency. Journal of Agriculture and Food Chemistry, 9(4),301-304.

Shafeek, M. R., Helmy, Y. I., Nadia, M., Rizk, Ö., \& Rizk F. A. (2013). Effect of foliar fertilizer with nutritional compound and humic acid on growth and yield, of broad bean plants under sandy soil conditions. Journal of Applied Sciences Research, 9(6), 3674-3680.

Singleton, V. L., Orthofer, R., \& Lamuela-Raventos, R. M. (1999). Analysis of total phenols and other oxidation substrates and antioxidants by means of Folin-Ciocalteu reagent. Methods Enzymol, 299,152-178.

Smith, N. G., \& Dukes, J. S. (2013). Plant respiration and photosynthesis in global-scale models: incorporating acclimation to temperature and CO2. Global Change Biology, 19(1), 45-63.

Taban, S., Çıkılı, Y., Kebeci, F., Taban, N., \& Sezer, S.M. (2004). Taşköprü yöresinde sarımsak tarımı yapılan toprakların verimlilik durumu ve potansiyel beslenme problemlerinin ortaya konulması. Ankara Üniversitesi Ziraat Fakültesi Tarım Bilimleri Dergisi, 10(3), 297-304.

Temesgen, T., Ayana, M., \& Bedadi, B. (2018). Evaluating the effects of deficit irrigation on yield and water productivity of furrow irrigated Onion (Allium cepa L.) in Ambo, Western Ethiopia. Irrigation \& Drainage Systems Engineering, 7, 1-6.

Türk, B., \& Şen, F. (2020). Determination of physicochemical characteristic of strawberry cultivars that grown in ManisaKöprübaşı. International Journal of Agriculture and Wildlife Science, 6(3),407-415.

Velikova, V., Yordanov, I., \& Edreva, A. (2000). Oxidative stress and some antioxidant systems in acid rain-treated bean plants. Plant Science, 151(1),59-66.

Vidya vani, M., Osman basha, P., \& Riazunnisa, K. (2019). Evaluation of biochemical responses of onion (Allium cepa L.) seedlings under drought stress. International Journal of Recent Scientific Research Research, 10(04), 31924-31927.

Vural, H., Eşiyok, D., \& Duman, İ. (2000). Kültür Sebzeleri (Sebze Yetiştirme). Ege Üniversitesi Basımevi, İzmir.

Wang, L., Wang, S., Chen, W., Li, H., \& Deng, X. (2017). Physiological mechanisms contributing to increased water-use efficiency in winter wheat under organic fertilization. PloS One, 12(6), 1-21.

Yazgan, S., Ayas, S., Demirtas, C., Büyükcangaz, H., \& Candogan, B. N. (2008) Deficit irrigation effects on lettuce (Lactuca sativa var. Olenka) yield in unheated greenhouse condition. Journal of Food Agriculture and Environment, 6, $357-361$.

Zhang, E., Duan, Y., Tan, F., \& Zhang, S. (2016). Effects of long-term nitrogen and organic fertilization on antioxidants content of tomato fruits. Journal of Horticulture, 3(1), 172.

Zoratti, L., Karppinen, K., Escobar, A. L., Häggman, H., \& Jaakola, L. (2014). Light-controlled flavonoid biosynthesis in fruits. Frontiers in Plant Science, 5(534), 534. 